\title{
Exploring Lecturers' Readiness for 21st Century Education in Malaysian Higher Learning Institutions
}

\author{
Syahrul Ahmar Ahmad ${ }^{1}$, Soo Kum Yoke ${ }^{2}$, Rahimah Mohamed Yunos ${ }^{3}$ and Juyati Mohd Amin ${ }^{4}$ \\ ${ }^{1}$ Faculty of Accountancy, Universiti Teknologi Mara Cawangan Johor. \\ ${ }^{2}$ Academy of Language Studies, Universiti Teknologi Mara Cawangan Johor. \\ ${ }^{3}$ Faculty of Accountancy, Universiti Teknologi Mara Cawangan Johor. \\ ${ }^{4}$ Faculty of Accountancy, Universiti Teknologi Mara Cawangan Johor.
}

\begin{tabular}{l} 
ARTICLE INFO \\
\hline Keywords: \\
21st century skills; higher \\
education; millennial \\
students; national \\
agenda; pedagogy.
\end{tabular}

\section{Introduction}

The nature of teaching to adopt the $21^{\text {st }}$ century education is paramount especially when dealing with the needs of $21^{\text {st }}$ century learners. These $21^{\text {st }}$ century learners are said to be the future workforce who are independent thinkers, problem solvers and decision makers (Silva, 2009, p. 
630). As such, there is a pertinent needs for educators to confront such important issues in preparing their students with the needs of $21^{\text {st }}$ century education skills. $21^{\text {st }}$ century education can be viewed as a vision of education promoted by various $21^{\text {st }}$ century learning models such as collaborative learning, use of ICT as tools for knowledge construction and co-construction, critical and creative thinking, and authentic problem solving (Chai \& Kong, 2017). Chai and Kong (2017) further asserted that the key factor for such transformation in education to happen is by having professional development programs for these educators. As such, students as the future workforce, need to be equipped with the required $21^{\text {st }}$ century skills and competencies in order for them to face the challenges of the future (Yoke, 2018). In order to fit the needs of the $21^{\text {st }}$ century workforce, the university needs to prepare their graduates to meet the expectations of potential employers.

While these graduates may have excellent academic records, this is not sufficient to make graduates career-ready, without inhibiting the traits of necessary soft skills generated through the process of learning (ACTE, 2014). Possessing excellent academic records and the necessary soft skills would allow them to secure them better careers and become better employees. However, it has been reported that many employers in Malaysia find fresh graduates from public universities as liabilities as many require additional training before they can perform well in the workplace (The Star, 2013). Further, there has also been reports that fresh graduates lack adaptability, multitasking skills, decision-making skills and problem-solving skills in the workplace (The Star, 2016a). Realizing this, the Ministry of Education has come out with the Malaysia Education Blueprint 2015 to 2025 (MEB) outlining the importance of having $21^{\text {st }}$ century skills integrated in the curriculum of Malaysian higher learning institutions. The blueprint essentially focused on the transformation of the higher education system to better prepare students for complexities and challenges of $21^{\text {st }}$ century employment. In order to fit the needs of the workforce, the university needs to prepare graduates to meet the expectations of potential employers. Such moves is demanded to embrace the coming of Digital Economy age as Trilling and Fadel (2009) argues that future students need to be equip with the sets of skills that would be most demanded in the $21^{\text {st }}$ century. That set of skills are referred to as the 4 Cs of the Learning and Innovations Skills domain which are i) critical thinking and problem solving, ii) communication, iii) collaboration and iv) creativity and innovation (Partnership for $21 \mathrm{st}$ Century Learning, 2007). However, the initiative needs to be in line with the competency of the educators and their pedagogical understanding of $21^{\text {st }}$ century skills to effectively provide such knowledge to their students.

In view of this, the present study intends to find out the extent of the implementation of $21^{\text {st }}$ century skills in tertiary education and the lecturers' pedagogical knowledge to facilitate the acquisition of the $21^{\text {st }}$ century skills among Malaysian tertiary students. This is highly significant in order to determine whether lecturers themselves are competent in the skills since they are the ones who are

going to align technologies with content and pedagogy. Specifically, the objectives of the study are as follows: (1) To identify educators' pedagogical understanding of $21^{\text {st }}$ century skills, and (2) to investigate whether the teaching methods adopted in the classroom are consistent with $21^{\text {st }}$ century skills. The findings would be relevant to the current education plan as recommendations can be made for the dissemination of $21^{\text {st }}$ century learning to be delivered by educators. 


\section{Literature review}

\subsection{Education in $21^{\text {st }}$ century}

Over the years, studies have been conducted to determine whether the education institutions are on the right path on preparing their students to face the challenges of the $21^{\text {st }}$ century, especially when they enter the workforce after they graduate. It is important for the education institutions, from the primary, secondary to the tertiary institutions to ensure that their policy, curriculum, and the teaching and learning process to be up-to-date with the current education practices to prepare the students with ample $21^{\text {st }}$ century skills. The concerns for $21^{\text {st }}$ century education is interwoven into the MEB as transformative efforts are put forth towards digital learning. Education in the $21^{\text {st }}$ century emphasizes learning of skills rather than content with the use of ICT facilities. Thus, it is imperative that educators and universities provide learning environments within which high-quality learning could be facilitated. Such learning environments include classroom setting, learning materials, learning activities and teaching strategies (Kivunja, 2014).

To promote these $21^{\text {st }}$ century skills, educators need to be innovative in their teaching and learning approaches in order to enhance their students' participation in the learning environment. Educators should use innovative strategies and modern learning technologies that help to integrate cognitive and social skills with content knowledge as well as increase student participation in the learning environment in order to promote these future skills (Alismail \& McGuire, 2015, p. 152). Furthermore, educators also need to create a supportive classroom environment, which could develop students' desire and ability to become independent and lifelong learners (Brickner \& Etter, 2008). Current educators also face challenges in their teaching pedagogy due to rapid changes in technology. Furthermore, another form of challenges face by these modern educators are current generations of students are of different generations from their educators. These generations would demand different type of school experience than their former generations (Greene \& Crespi, 2012; Hofer \& Swan, 2005). Current generations of students, known as the millennial generation, is considered to be unique as they are multitaskers, having short attention spans and relying so much on digital technology (Hofer \& Swan, 2005; Phillips \& Trainor, 2014). Recognizing this symptom is essential for educators to enable them to plan their class lessons more effectively.

\subsection{Educators' readiness}

Not only does the focus of education is different, the roles of educators (teachers and lecturers) between the two centuries $\left(20^{\text {th }}\right.$ and $\left.21^{\text {st }}\right)$ are different. During the previous $20^{\text {th }}$ century, the focus was more on the teaching of reading, writing and arithmetic skills. As for the needs of the $21^{\text {st }}$ century, educators are required to be facilitators, critical and open minded, collaborators, mediators, and most importantly, they are expected to be technologically oriented (Amin, 2016; Pavlovic \& Petrovic, 2017). It could be seen that educators have more active and complicated roles, and they are not only expected to impart knowledge to their students. All of these roles and habits are important for the $21^{\text {st }}$ century educators to possess to help mold the students to be more independent learners as well as to shy away from the traditional classroom. In the $21^{\text {st }}$ century education, a student-centered classroom is more fitting than a teacher-centered classroom. 
History dictates that most educators today have been trained to teach and manage classrooms in an era where technology was not widespread. Educators in their 40s, born in the 1960s and 1970s have witness the evolution of technology in their lives as digital immigrants of technology. Students born in the year 2000 onwards however, are digital natives of technology with early exposure to widespread use of technology. Hence, in order to be able to teach in this techno-savvy environment, there is no choice but for educators to keep up with the technology. Chai and Kong (2017) asserted that current technology trends have raised many challenges to didactic teaching and learning in traditional classrooms. As such, many educators are now turning to and advocating $21^{\text {st }}$ century learning.

In view of this, some educators seem less enthusiastic in accepting change. Yoke (2018) asserted that transformation in education is bound to take place with or without readiness from educators as the change is global in all aspects of daily lives. If educators are not up to the challenge then they would be left behind. The key for transformation in education to take place is professional development for educators. Tsai and Chai (2012) stated that developing educators' competencies for $21^{\text {st }}$ century teaching and learning would include transforming their knowledge, beliefs, and design capacities for the benefit of learners. In sum, it is then evident that educators' readiness is essential for the promotion of $21^{\text {st }}$ century education so that they can effectively conduct teaching and learning in a technology driven environment.

\subsection{The $21^{\text {st }}$ century skills}

The study focuses on the 4Cs of the Learning and Innovations Skills domain which are i) critical thinking and problem solving, ii) communication, iii) collaboration and iv) creativity and innovation (Partnership for 21st Century Learning, 2007).

\subsubsection{Critical thinking}

There are several definitions of critical thinking and all centralized in the ability of a person to process knowledge in order to make decision (Dilley, Kaufman, Kennedy, \& Plucker, 2015). The Bloom Taxonomy categorized the taxonomy into three sections-cognitive, affective, and psychomotor. The cognitive element is the most relevant in developing critical thinking that include six categories: Knowledge, Comprehension, Application, Analysis, Synthesis, and Evaluation. Evidence showed that teaching method had significant impact on student ability to develop critical thinking. For instance, Nold (2017) identified that students critical thinking had improved after administering them over 8 weeks course period. It was concluded that students who were exposed to multiple written assignments and were given task to provide feedback on logic from research project improved significantly on critical thinking skill. Online discussion forums and team presentations to the class would also improve critical thinking skill when instructors challenge the students' posts and presentation to demand deeper thinking.

\subsubsection{Communication}

Communication skill are abilities in listening, speaking, observing and empathizing. This skill also allows a person to receive and deliver different kind of information in his surroundings. This is the first skill assess by the employer during the job interview. Developing communication skill into student would require correct guidance from the educators and assessments assigned to the students. Claro et al. (2018) showed that, one-fourth of the educator have difficulty to teach student on how to solve information and communication tasks. They 
also found that the educators are not able to complete task related to collaborating with others remotely, organizing and summarizing information, and quoting the work of others resulting to the absences of processing information in digital environment skill among the students. Riemer (2007) who studied communication skills for engineer stated that, oral communication is learnable skill and it can be developed through several assessments, i.e. presentations, peerreview, role-play and video presentations.

\subsubsection{Collaboration}

It is crucial to carry out students activities that helps to develop collaboration skill as proven from Bowen and Shume (2018) study. It was reported that teachers who were send for externship experienced themselves, most of job done in the workforce involve collaboration. There was individual project but other projects were mainly team work. Several studies examined the benefits of Project-based Learning (PBL) in developing collaborative skill. PBL is a motivating approach that require student to highly engage in the learning process and attract them to get involve and interest. At the beginning cycle of their success, their self-esteem increases (Doppelt, 2003). Interesting note made by Bell (2010), educators may evaluate students based on rubric but the PBL permits self-evaluation and reflection because the students feel how they responded and collaborate through the discussion and in helping their colleague to come out with the project outcome.

\subsubsection{Creativity}

Plucker and Beghet (2004) define creativity as, "Creativity is the interaction among aptitude, process, and environment by which an individual or group produces a perceptible product that is both novel and useful as defined within a social context" (p. 90). Plucker, Kaufman and Beghetto $(2015$, p. 1) explained that creativity is " ... the ability to produce and implement new, useful ideas is rapidly becoming a critical attribute for leveraging knowledge success and increasing quality of life". Virtanen and Tynjälä (2018) identified that student ability to be creative depend on how positive the atmosphere of the learning situation. Additionally, they have less ability to be creative if hearing too much lecturing and performing too much individual activities rather than in group.

\subsubsection{Using technology as a tool for learning}

According to Hofer and Swan (2005), $21^{\text {st }}$ century students who are also known as millennial students are multitasked who prefer to be involved in active learning involving technology rather than note taking from lecture given by the instructor. Studies have shown that incorporating technology into teaching has reduced problems to engage in teaching activities to promotes other $21^{\text {st }}$ century skills (Sang, Liang, Chai, Dong, \& Tsai, 2018). This is consistent with Howland, Jonassen and Marra (2012) who stated that technology allows meaningful learning for all other $21^{\text {st }}$ century learning skills. Educators should be aware that possessing these skill enable students to survive when they enter into the job market. Furthermore, the learning preference of the Gen $\mathrm{Z}$ students are different students from the previous generation as they are more hands-on and directly involved in the learning process (Hussin, 2018, p. 93). 


\section{Research methodology}

\subsection{Survey instrument}

The study utilised a survey instrument adapted from the work developed by Hixson, Ravitz, and Whisman (2012), who developed it from the previous work of Innovative Teaching and Learning study (Shear, Novais, Means, Gallagher, \& Langworthy, 2010), Deeper Learning framework (The William and Flora Hewlett Foundation, 2010) and Partnership for $21^{\text {st }}$ Century Skills (2011). The survey addressed five teaching skills domain that are recognised in the literature that support the acquisition of the $21^{\text {st }}$ century learning education (refer Table 1).

Table 1: Survey instrument developed by Hixson, Ravitz, and Whisman (2012)

\begin{tabular}{|l|l|}
\hline \multicolumn{1}{|c|}{ Area } & \multicolumn{1}{c|}{ Content of Area } \\
\hline $\begin{array}{l}\text { CRITICAL } \\
\text { THINKING SKILLS }\end{array}$ & $\begin{array}{l}\text { refer to students being able to analyze complex problems, investigate questions } \\
\text { for which there are no clear-cut answers, evaluate different points of view or } \\
\text { sources of information, and draw appropriate conclusions based on evidence and } \\
\text { reasoning. }\end{array}$ \\
\hline $\begin{array}{l}\text { COLLABORATION } \\
\text { SKILLS }\end{array}$ & $\begin{array}{l}\text { questions, to work effectively and respectfully in teams to accomplish a common } \\
\text { goal and to assume shared responsibility for completing a task. }\end{array}$ \\
\hline $\begin{array}{l}\text { COMMUNICATION } \\
\text { SKILLS }\end{array}$ & $\begin{array}{l}\text { refer to students being able to organize their thoughts, data and findings and share } \\
\text { these effectively through a variety of media, as well as orally and in writing. }\end{array}$ \\
\hline $\begin{array}{l}\text { CREATIVITY AND } \\
\text { INNOVATION }\end{array}$ & $\begin{array}{l}\text { refer to students being able to generate and refine solutions to complex problems } \\
\text { or tasks based on synthesis, analysis and then combining or presenting what they } \\
\text { have learned in new and original ways. }\end{array}$ \\
\hline $\begin{array}{l}\text { USING } \\
\text { TECHNOLOGY AS } \\
\text { LEARNING }\end{array}$ & $\begin{array}{l}\text { refers to students being able to manage their learning and produce products using } \\
\text { appropriate information and communication technologies. }\end{array}$ \\
\hline
\end{tabular}

Each section of the survey provides (1) the above definition, and (2) a list of related practices. The survey asked about the frequency of five to eight such practices for each skill (e.g., having students work in groups to support collaboration). Response choices were 1 'Almost never'; 2 'A few times a semester'; 3 '1-3 times per month'; 4 '1-3 times per week'; 5 'Almost daily'. 


\subsection{Participants}

The survey was administered to lecturers from various public higher learning institutions across Malaysia. The survey was collected through online medium (Google Form). The online medium was resorted as provides easy access to participants from various distant locations, and the convenience of having automated data collection, which reduces time and effort (Wright, 2005). Initially, emails were sent at random to these public higher learning institutions' lecturers, inviting them to participate in the study. The study collected 142 completed online questionnaires responses.

\subsection{Data analysis}

The responses from Google Form were transferred to the Statistical Package for Social Sciences (SPSS) for processing the data. The analysis was conducted according to the objectives of the study. Descriptive statistics were used to describe and summarize the properties of the mass of data collected from school principals. Mean scores, standard deviations and percentages were calculated per each item of the survey instrument.

\section{$4 \quad$ Results and discussion}

\subsection{Demographic data}

Table 2 shows the demographic profiles of the respondents involved in this study. Based on the table, majority were female respondents (74.6\%). On the respondents' years of service in education, majority were in the range between 1 to 5 years $(25.4 \%)$ and 6 to $10(22.5 \%)$ years of range in their teaching experience. The study also asked the respondents' field of teaching which is grouped under two categories - Social Sciences and STEM (Science, Technology, Engineering and Mathematics). Examples of fields of teaching categorized under Social Sciences are Education, Language, Islamic Studies, Business, and others. Meanwhile, the examples of field of teaching under STEM would be Mathematics, Engineering, Accounting, Chemistry, and others. Majority of the respondents teach Social Sciences subject (71.8\%). 
Table 2: Demographic profiles of respondents

\begin{tabular}{|c|c|c|c|c|}
\hline & & & No & $\%$ \\
\hline \multirow[t]{3}{*}{ Gender } & Female & & 106 & 74.6 \\
\hline & $\underline{\text { Male }}$ & & $\underline{36}$ & $\underline{25.4}$ \\
\hline & & Total & 142 & 100.0 \\
\hline \multirow[t]{8}{*}{$\begin{array}{l}\text { Years of } \\
\text { Service }\end{array}$} & $\begin{array}{l}\text { Less than } 1 \\
\text { year }\end{array}$ & & 5 & 3.5 \\
\hline & $1-5$ years & & 36 & 25.4 \\
\hline & $6-10$ years & & 32 & 22.5 \\
\hline & $11-15$ years & & 28 & 19.7 \\
\hline & $16-20$ years & & 22 & 15.5 \\
\hline & $21-25$ years & & 15 & 10.6 \\
\hline & $\underline{26-30 \text { years }}$ & & $\underline{4}$ & $\underline{2.8}$ \\
\hline & & Total & 142 & 100.0 \\
\hline \multirow[t]{3}{*}{$\begin{array}{l}\text { Field of } \\
\text { Teaching }\end{array}$} & $\begin{array}{l}\text { Social } \\
\text { Sciences }\end{array}$ & & 102 & 71.8 \\
\hline & $\underline{\text { STEM }}$ & & $\underline{40}$ & $\underline{28.2}$ \\
\hline & & Total & 142 & 100.0 \\
\hline
\end{tabular}

\subsection{Respondents' understanding of $21^{\text {st }}$ century skills}

The first research objective of this study is to identify the Malaysian lecturers' pedagogical understanding of $21^{\text {st }}$ century skills. Questions were assessed using a 5-point Likert scale $(1=$ "Do not know", 2 = "Strongly agree", 3 = "Agree", 4 = "Disagree", and 5 = "Strongly disagree"). The results of the analysis are as table below. 
Table 3: Descriptive statistics on Lecturers' understanding of $21^{\text {st }}$ Century Skills

\begin{tabular}{|c|c|c|}
\hline Statements & $\begin{array}{l}\text { Mean } \\
(\mathrm{M})\end{array}$ & $\begin{array}{l}\text { Std. Dev } \\
\text { (SD) }\end{array}$ \\
\hline 5a) I possess an excellent understanding of 21 st century skills. & 2.66 & .77 \\
\hline 5b) I frequently engage students in lessons and activities that promote creativity. & 2.64 & .70 \\
\hline $\begin{array}{l}\text { 5c) I frequently engage students in lessons and activities that promote critical } \\
\text { thinking. }\end{array}$ & 2.55 & .65 \\
\hline $\begin{array}{l}\text { 5d) I frequently engage students in lessons and activities that promote problem } \\
\text { solving. }\end{array}$ & 2.62 & .67 \\
\hline $\begin{array}{l}\text { 5e) I frequently engage students in lessons and activities that promote } \\
\text { communication and collaborations. }\end{array}$ & 2.36 & .64 \\
\hline $\begin{array}{l}\text { 5f) } 21 \text { st century higher-level skills are important for students' future success in the } \\
\text { workplace. }\end{array}$ & 2.19 & .59 \\
\hline $\begin{array}{l}5 \mathrm{~g}) \text { I have a need for professional development to INCREASE my knowledge of } \\
21 \text { st century skills. }\end{array}$ & 2.34 & .69 \\
\hline $\begin{array}{l}\text { 5h) I have a need for professional development to CREATE LESSONS for } 21 \text { st } \\
\text { century skills. }\end{array}$ & 2.37 & .76 \\
\hline 5i) Technology plays a vital role in supporting 21 st century learning. & 2.22 & .65 \\
\hline $\begin{array}{l}\text { 5j) I am confident with using technology as a tool to teach } 21 \text { st century higherlevel } \\
\text { skills. }\end{array}$ & 2.44 & .71 \\
\hline Overall understanding of $21^{\text {st }}$ century skills & 2.44 & .44 \\
\hline
\end{tabular}

The overall mean score of the respondents' understanding of $21^{\text {st }}$ century skills is $2.44(\mathrm{SD}=$ .44) which shows that these lecturers do pose strong pedagogical understanding about $21^{\text {st }}$ century skills. Based on the table above, the statement with the lowest mean score (closest to "Strongly Agree) is statement $5 \mathrm{f}(\mathrm{M}=2.19, \mathrm{SD}=.59)$ which indicated that these lecturers agree that the $21^{\text {st }}$ century skills are important for their students' future career success. This is then followed by statement $5 \mathrm{i}(\mathrm{M}=2.22, \mathrm{SD}=.65)$ where they acknowledged that the use of technology is vital in supporting

$21^{\text {st }}$ century learning. On the other hand, the statements with the highest mean scores are $5 \mathrm{a}(\mathrm{M}$ $=2.66, \mathrm{SD}=.77)$ and $5 \mathrm{~b}(\mathrm{M}=2.64, \mathrm{SD}=.70)$. Although the results are not really material but it could indicate that some lecturers may not be having a good understanding about $21^{\text {st }}$ century education and its pedagogical approach. However, it could be concluded that most respondents agreed that the $21^{\text {st }}$ century skills are important for the students' future success in the workplace. In general, the respondents perceived that they have quite a strong understanding of $21^{\text {st }}$ century skills education that need to be imparted to their students. 


\subsection{Analysis of teaching methods of developing $21^{\text {st }}$ century skills}

The following tables measured the respondents' different methods of developing the $21^{\text {st }}$ century skills during their teaching and learning process in the classroom. The five methods analysed for this study were: 1) critical thinking skills, 2) collaboration skills, 3) communication skills, 4) creativity and innovation skills, and 5) the use of technology as tools for learning. Questions for each methods were assessed using a 5-point Likert scale (1 = "Almost never", 2 = "A few times a semester", $3=$ " $1-3$ times per month", $4=$ " $1-3$ times per week", and $5=$ "Almost daily"). The results of the analysis are as table below.

\subsubsection{Critical thinking skills}

Table 4: Methods of developing the critical thinking skills

\begin{tabular}{|c|c|c|}
\hline Methods & Mean (M) & $\begin{array}{l}\text { Std. Dev } \\
\text { (SD) }\end{array}$ \\
\hline $\begin{array}{l}\text { 6a) Compare information from different sources before completing a task or } \\
\text { assignment. }\end{array}$ & 2.81 & 1.12 \\
\hline $\begin{array}{l}\text { 6b) Draw their own conclusions based on analysis of numbers, facts, or relevant } \\
\text { information. }\end{array}$ & 3.06 & 1.10 \\
\hline 6c) Summarize or create their own interpretation of what they have been taught. & 3.14 & 1.04 \\
\hline 6d) Analyse arguments, perspectives or solutions to a problem. & 3.00 & 1.05 \\
\hline 6e) Develop a persuasive argument based on supporting evidence or reasoning. & 2.94 & 1.08 \\
\hline $\begin{array}{l}\text { 6f) Try to solve complex problems or answer questions that have no single correct } \\
\text { solution or answers. }\end{array}$ & 2.94 & 1.06 \\
\hline Overall score of developing critical thinking skills & 2.98 & .95 \\
\hline
\end{tabular}

In developing their students' critical thinking skills, these lecturers did their best to address critical thinking skills in their teaching $(\mathrm{M}=2.98, \mathrm{SD}=0.95)$. Overall they address their students' critical thinking skills in their classroom for few times a semester, which is relatively above the average 5point scale. In terms of their teaching approach, the most common approach taught in the classroom by these lecturers was method 6c - "Summarize or create their own interpretation of what they have been taught" $(\mathrm{M}=3.14, \mathrm{SD}=1.04)$ and this was followed by method 6b - "Draw their own conclusions based on analysis of numbers, facts, or relevant information" $(\mathrm{M}=3.06, \mathrm{SD}=1.10)$. The least common method is utilised by them was method 6a - "Compare information from different sources before completing a task or assignment" (M $=2.81, \mathrm{SD}=1.12$ ).

\subsubsection{Collaboration skills}

In terms of their approach in enhancing their students' collaboration skills, Table 5 clearly indicated that collaboration skills is commonly addressed on monthly basis among their students $(\mathrm{M}=3.03, \mathrm{SD}=.98)$. All methods were employed in their teaching approach and were relatively above the mean 5-point scale. The most preferred approach by these lecturers to thrive their students' collaboration skill is by requiring them to work either in pairs or small groups to 
complete a given task (method 7a) $(\mathrm{M}=3.30, \mathrm{SD}=1.06)$. This is then followed by methods $7 \mathrm{~d}$ and 7e which saw that the lecturers regularly asked their students to do presentations as well as requiring their students to provide feedbacks.

Table 5: Methods of developing the collaboration skills

\begin{tabular}{llc}
\hline \multicolumn{1}{c}{ Methods } & Mean (M) & $\begin{array}{c}\text { Std.Dev } \\
\text { (SD) }\end{array}$ \\
\hline 7a) Work in pairs or small groups to complete a task together. & 3.30 & 1.06 \\
7b) Work with other students to set goals and create a plan for their team. & 3.04 & 1.09 \\
7c) Create joint products using contributions from each student. & 2.68 & 1.15 \\
7d) Present their group work to the class, lecturer or others. & 3.14 & 1.11 \\
7e) Work as a team to incorporate feedback on group tasks or products. & 3.13 & 1.08 \\
7f) Give feedback to peers or assess other students' work. & 2.89 & 1.26 \\
\hline Overall score of developing collaboration skills & 3.03 & .98 \\
\hline
\end{tabular}

\subsubsection{Communication skills}

Table 6: Methods of developing the communication skills

\begin{tabular}{|c|c|c|}
\hline Methods & Mean (M) & $\begin{array}{ll}\text { Std. } & \text { Dev } \\
\text { (SD) }\end{array}$ \\
\hline $\begin{array}{l}\text { 8a) Structure data for use in written products or oral presentation (e.g: creating } \\
\text { chart, tables or graphs). }\end{array}$ & 2.59 & 1.03 \\
\hline $\begin{array}{l}\text { 8b) Convey their ideas using media other than a written paper (e.g: poster, } \\
\text { video, blog, etc). }\end{array}$ & 2.67 & 1.07 \\
\hline 8c) Prepare and deliver an oral presentation to the lecturer or others. & 3.01 & 1.04 \\
\hline 8d) Answer questions in front of an audience. & 3.19 & 1.16 \\
\hline 8e) Decide how they will present their work or demonstrate their learning. & 2.95 & 1.14 \\
\hline Overall score of developing communication skills & 2.88 & .93 \\
\hline
\end{tabular}

The finding shows that communication skills is regularly address by these lectures $(\mathrm{M}=2.88$, $\mathrm{SD}=.93$ ). Interestingly, the most regular approach adopted by these higher learning institutions educators is to ask their students to answer questions in front of audience (method 8d) (M = $3.19, \mathrm{SD}=1.16)$. This is then followed by method $8 \mathrm{c}$ - "Prepare and deliver an oral presentation to the lecturer or others" $(\mathrm{M}=3.01, \mathrm{SD}=1.04)$. All other methods were employed in their teaching approach and were relatively above the mean 5-point scale.

\subsubsection{Creativity and innovation skills}

The need to impart creativity and innovation skills was also regularly addressed by these lecturers $(\mathrm{M}=2.78, \mathrm{SD}=1.01)$. It can be seen that despite on the need to complete their syllabus within the given semester, these lectures took some time to incorporate such skill in their classrooms. The most common approach was methods $9 \mathrm{~b}$ followed by $9 \mathrm{a}$, which saw that these lecturers require their students to generate their own ideas towards a particular problem $(\mathrm{M}=$ 
$2.99, \mathrm{SD}=1.08)$ and created a brain storming or concept mapping techniques $(\mathrm{M}=2.92, \mathrm{SD}=$ 1.16). All other methods were seen to be employed relatively above the mid 5-point scale.

Table 7: Methods of developing the creativity and innovation skills

\begin{tabular}{llc}
\hline \multicolumn{1}{c}{ Methods } & Mean (M) & $\begin{array}{l}\text { Std. } \\
\text { (SD) }\end{array}$ \\
\hline 9a) Use idea creation techniques such as brainstorming or concept mapping. & 2.92 & 1.16 \\
9b) Generate their own ideas about how to confront a problem or question. & 2.99 & 1.08 \\
9c) Test out different ideas and work to improve them. & 2.78 & 1.14 \\
9d) Invent a solution to a complex, open-ended question or problem. & 2.65 & 1.10 \\
9e) Create an original product or performance to express their ideas. & 2.54 & 1.15 \\
\hline Overall score of developing creativity and innovation skills & 2.78 & 1.01 \\
\hline
\end{tabular}

\subsubsection{Using technology as a tool for learning}

Table 8: Methods of developing the use of technology as a tool for learni

Methods

Mean (M)

Std. Dev

(SD)

10a) Use technology or the internet for self-instruction (e.g: Kahn academy or other videos, tutorials, self-instructional websites).

2.75

2.83

2.74

10c) Evaluate the credibility and relevance of online resources.

10d) Use technology to analyse information (e.g: databases, spreadsheets, graphic programs).

10e) Use technology to help them share information (e.g: multi-media presentations using sound or video, presentation software, blogs, podcast).

10f) Use technology to support team work or collaboration (e.g: shared work spaces, email exchanges, giving and receiving feedback).

$10 \mathrm{~g})$ Use technology to interact directly with experts or members of local/global communities.

10h) Use technology to keep track of the work on extended tasks or assignments.

Overall mean score of using technology as tool for learning

This final table presents the approached used by the lecturers in enhancing the use of technology in their class. The average mean score was 2.74 indicating that such skill was address regularly in the teaching and learning environment. The highest mean on the methods adopted to address this type of skill is method 10e - "Use technology to help them share information (e.g: multimedia presentations using sound or video, presentation software, blogs, podcast)". Surprisingly, the study would expect the use of such approach should be much higher as higher learning institutions' classes are supposed to be equipped with technology-enabled-classrooms (TEC). Similarly with method $10 \mathrm{f}$ which is the second most applied. Despite having a number of $21^{\text {st }}$ education tools and software such as Google Classroom, Padlet, Kahoot, Blendspace and etc., 
it seems that these lecturers do not adopt such tools effectively. Among the five teaching methods adopted, this is the lowest skill approach utilised by the lecturers. Nevertheless, all the methods applied indicated mean scores of all above the mean 5-point Likert scale, except method $10 \mathrm{~g}$ - "Use technology to interact directly with experts or members of local/global communities" $(\mathrm{M}=2.45, \mathrm{SD}=1.22)$.

Overall, the study reveals that, all these lecturers have a certain type of knowledge to address the needs of the students in acquiring all the five pertinent skills of $21^{\text {st }}$ century education. The results shown that none of those five skills were below the average of 5-points Likert scale, with collaboration skills being the highest $(\mathrm{M}=3.03)$ and use of technology as a tool for learning was the lowest $(\mathrm{M}=2.74)$.

\section{$5 \quad$ Discussion and conclusion}

The study explored Malaysian lecturers' understanding and their implementation methods on the $21^{\text {st }}$ century skills within their teaching and learning approach. Specifically, the study would like (1) to identify the Malaysian lecturers' pedagogical understanding of $21^{\text {st }}$ century skills, and (2) to investigate whether the teaching methods adopted in their classroom are consistent with $21^{\text {st }}$ century skills. On the first objective, it shows that these Malaysian lecturers claimed to have strong understanding about the importance of pedagogical approach in disseminating the needs of this $21^{\text {st }}$ century learning skills in their classrooms. Despite coming from various types of background (gender, years of service and field of teaching), these lecturers acknowledged on the importance of the transformation of education which is meant for their current digital natives students. As Kivunja (2014, p. 89) put it, it is a professional imperative that lecturers need to fulfil the moral purpose of education: to make each of their graduates a productive citizen in the 21st century economy. Consistent with Yoke (2018), the need for transformation in education is bound to take place even if they themselves are not ready.

On the second objective, the study explored these lecturers' choices of various methods in developing the $21^{\text {st }}$ century skills within their teaching and learning processes. The five methods analysed for this study were: 1) critical thinking skills, 2) collaboration skills, 3) communication skills, 4) creativity and innovation skills, and 5) the use of technology as tools for learning as described by Partnership for 21st Century Learning (2007). The results showed that none of these five skills were neglected by these lecturers in their teaching and learning approaches. However, as the study was conducted among the lecturers of higher learning institutions, it would be expected that all those five skills should be emphasized and addressed more frequently by these academicians. This is due to when educators engaging their students in one of the $21^{\text {st }}$ century skill, the other types of skills are engaged in varying degrees (Germaine, Richards, Koeller, \& Scubert-Irastorza, 2016). As such, all those five methods of $21^{\text {st }}$ century skills are intertwined.

Somehow, out of those five learning skills, the use of technology as learning tool is not frequently applied as it should by these lecturers. The use of technology in teaching and learning should be emphasized more thoroughly as these lecturers are actually dealing with digital native generation of students. Howland et al. (2012) have said that technology would allow meaningful learning for all other $21^{\text {st }}$ century learning skills. Furthermore, studies have stressed the importance of embedding technology as a tool for $21^{\text {st }}$ century pedagogy and curriculum (Kivunja, 2014; Trilling \& Fadel, 2009). As such, these lecturers need to equip themselves as 
well as learn various type of digital tools to meet the learning preference of their digital native students. There are various types of digital tools that these lecturers can choose from online (see Educational Technology and Mobile Learning, 2016). The use of these digital tools are mostly preferred by these generation of students as it allows them to be integrated into learning process (Hussin, 2018)

As a conclusion, the study showed that the $21^{\text {st }}$ century learning skills were being imparted by Malaysian higher education lecturers. The findings showed that Malaysian lecturers have taken into considerations on the essence of Malaysian Education Blueprint 2015 -2025 to prepare their students with the needs of $21^{\text {st }}$ century education. As higher education stands as a hallmark for providing human capital for future development of this country, it is important that the education system is able to equip Malaysian undergraduates for the workforce in the $21^{\text {st }}$ century environment. As such, it is important for the university administrators as well as the universities" academic affairs division to conduct a specialized programs to address the importance of $21^{\text {st }}$ century education among its lecturers. Such program may include curriculum review as well as professional training and development program for their academicians. Besides, the administrators need to acknowledge on the needs to provide better facilities to support and embrace this evolving and vibrant $21^{\text {st }}$ century education.

\section{Acknowledgements}

This paper draws from a grant awarded by the Ministry of Higher Education (MOHE), Malaysia under the Fundamental Research Grant Scheme Phase 1/2017, RMC File No. 600-IRMI/FRGS $5 / 3(055 / 2017)$.

\section{References}

ACTE. (2014). ACTE: Voices support for pathways to Prosperity Act of 2014. Retrieved from http://www.acteonline.org/general.aspx?id=6572\#.U7BVVPldWS

Alismail, H. A., \& McGuire, P. (2015). 21 st century standards and curriculum: Current research and practice. Journal of Education and Practice, 6(6), 150-155.

Amin, J. N. (2016). Redefining the role of teachers in the digital era. The International Journal of Indian Psychology, 3(6), 40-45.

Bell, S. (2010). Project-based learning for the 21st century: Skills for the future. The Clearing House: A Journal of Educational Strategies, Issues and Ideas, 83(2), 39-43.

Bowen, B., \& Shume, T. (2018). Educators in industry: An exploratory study to determine how teacher externships influence K-12 classroom practices. Journal of STEM Education, 19(1), 5762.

Brickner, D. R. ., \& Etter, E. R. E. (2008). Strategies for promoting active learning. Academy of Educational Leadership Journal, 12(2), 87-93.

Chai, C. S., \& Kong, S.-C. (2017). Professional learning for 21st century education. Journal of Computers in Education, 4(1), 1-4.

Claro, M., Salinas, A., Cabello-Hutt, T., San Martín, E., Preiss, D. D., Valenzuela, S., \& Jara, I. (2018). Teaching in a digital environment (TIDE): Defining and measuring teachers' capacity to develop students' digital information and communication skills. Computers and Education, 121(November), 162-174.

Dilley, A., Kaufman, J. C., Kennedy, C., \& Plucker, J. A. (2015). What we know about critical thinking. Part of the 4Cs Research Series US: Partnership for 21st Century Skills. 
Doppelt, Y. (2003). Implementation and assessment of project-based learning in a flexible environment. International Journal of Technology and Design Education, 13(3), 255-272.

Educational Technology and Mobile Learning. (2016). 9 Fundamental Digital Skills for 21st Century Teachers. Retrieved from https://www.educatorstechnology.com/

Germaine, R., Richards, J., Koeller, M., \& Scubert-Irastorza, C. (2016). Purposeful use of 21st century skills in higher education. Journal of Research in Innovative Teaching, 9(1), 2-17.

Greene, H., \& Crespi, C. (2012). The value of student created videos in the college classroom - An exploratory study in Marketing and Accounting. International Journal of Arts \& Sciences, 5(51), 273-283.

Hixson, N. K., Ravitz, J., \& Whisman, A. (2012). Extended Professional Development in ProjectBased Learning: Impacts on 21st Century Skills Teaching and Student Achievement. Charleston, WV: West Virginia Department of Education. Retrieved from https://www.academia.edu/1999374

Hofer, M., \& Swan, K. O. (2005). Digital moviemaking - The harmonization of technology, pedagogy and content. International Journal of Technology in Teaching and Learning, 1(2), $102-110$.

Howland, J. L., Jonassen, D., \& Marra, R. M. (2012). Meaningful learning with technology (4th ed.). Boston.

Hussin, A. A. (2018). Education 4.0 made simple: Ideas for teaching. International Journal of Education and Literacy Studies, 6(3), 92.

Kivunja, C. (2014). Do you want your students to be job-ready with 21 st Century skills? Change pedagogies: A pedagogical paradigm shift from vygotskyian social constructivism to critical thinking, problem solving and siemens' digital connectivism. International Journal of Higher Education, 3(3), 81-91.

Nold, H. (2017). Using critical thinking teaching methods to increases student success: An action research project. International Journal of Teaching and Learning in Higher Education, 29(1), 17-32.

Partnership for 21st Century Learning. (2007). Framework for 21st Century Learning . Retrieved from http://www.p21.org/our-work/p21-framework

Partnership for 21st Century Skills. (2011). No Title. Retrieved from http://www.p21.org

Pavlovic, D., \& Petrovic, Z. S. (2017). Potentials and limitations of the internet use in the learning process. Bulgarian Journal of Science and Education Policy, 11(2), 220-232.

Phillips, C. R., \& Trainor, J. E. (2014). Millennial students and the flipped classroom. Journal of Business and Educational Leadership, 21(1), 519-531.

Plucker, J. A., \& Beghet, R. A. (2004). Why creativity is domain general, why it looks domain specific, and why the distinction does not matter. In R. J. Sternberg, E. L. Grigorenko, \& J. L. Singer (Eds.) (pp. 153-168). Washington, DC: American Psychological Association.

Plucker, J. A., Kaufman, J., \& Beghetto, R. (2015). What we know about creativity. Part of the 4Cs Research Series US: Partnership for 21st Century Skills.

Riemer, M. J. (2007). Communication skills for the 21st century engineer. Global Journal. of Engineering Education, 1(1), 89-100.

Sang, G., Liang, J. C., Chai, C. S., Dong, Y., \& Tsai, C. C. (2018). Teachers' actual and preferred perceptions of twenty-first century learning competencies: A Chinese perspective. Asia Pacific Education Review, 19(3), 307-317.

Shear, L., Novais, G., Means, B., Gallagher, L., \& Langworthy, M. (2010). ITL Research Design. Menlo Park, CA: SRI International. 
Silva, E. (2009). Measuring skills for 21st-century learning. Phi Delta Kappan, 90(9), 630-634. The William and Flora Hewlett Foundation. (2010). Education Program Strategic Plan. Education. Menlo Park, CA: SRI International.

Trilling, B., \& Fadel, C. (2009). 21st Century Skills: Learning for Life in Our Times. San Francisco, California: Jossey-Bass.

Tsai, C. C., \& Chai, C. S. (2012). The "third"-order barrier for technology-integration instruction: Implications for teacher education. Australasian Journal of Educational Technology, 28(6), 1057-1060.

Virtanen, A., \& Tynjälä, P. (2018). Factors explaining the learning of generic skills: A study of university students' experiences. Teaching in Higher Education, 1-15.

Wright, K. B. (2005). Researching internet-based populations: Advantages and disadvantages of online survey research, online questionnaire authoring software packages, and web survey services. Journal of Computer-Mediated Communication, 10(3).

Yoke, S. K. (2018, April 28). Shaping education for future employment. The New Straits Times. Retrieved from https://www.nst.com.my/opinion/letters/2018/04/362689/shapingeducationfuture-employment 